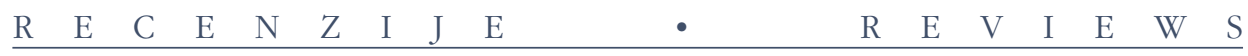

Matjaž Barbo

\title{
Slovenska muzikologija: Kratek prelet po zgodovini
}

Matjaž Barbo. Slovenska muzikologija: Kratek prelet po zgodovini. Historia facultatis. Ljubljana: Založba Filozofske fakultete, 2019. 134 strani. ISBN 978-961-06-0152-4.

Slovenska muzikologija Matjaža Barba, četudi obljublja le kratek prelet, je bistveno več kot le to. Je očrt tega, kar se je s slovensko muzikologijo v zadnjih 800 letih dogajalo, hkrati pa je tudi izjemen vir podatkov in zanimivih dejstev, ki so bila do sedaj malo poznana. Avtor že v predgovoru napiše, da se njegova razprava ne osredotoča na muzikologijo z vidika točke nič (tj. njeno umestitvijo med sedem muz Filozofske fakultete), ampak da želi preučiti njene izvire. Začne v 14. stoletju, pri cistercijanih, v Stični, centru sveta za nastajajoči osnutek slovenskega naroda.

Novoveški slovenski doprinos k muzikologiji je prikazan skozi spekter različnih avtorjev - Janeza Schönlebna, Janeza Krstnika Dolničarja in Janeza Gregorja Dolničarja. Vsi trije so v sorodu: oba Dolničarja sta prek matere Marije Ane nečaka Janeza Schönlebna. Barbo v svoji analizi omeni Schönlebnovo delo Carniola antiqua et nova sive Annales sacroprophani (str. 12), ki po njegovem mnenju predstavlja izvrsten vir (tudi) glasbene preteklosti na Kranjskem. Barbo opozori tudi na pomen Janeza Gregorja za razvoj (posvetne) glasbe, ki se je zavzemal za izgradnjo bogoslovnega semenišča zato, da »bodo kleriki [...] tudi sodelavci med godbeniki« (str. 13). V tem poglavju Barbo opozarja še na zgodovinsko notno knjižico novomeškega organista oz. organistov (Noten-Buch darinnen die Fundamenta zu dem Clavier oder Orgel enthalten) (str. 14), ki je v širši glasbeni skupnosti premalo poznana. Bi jo pa morali, tudi zaradi državniških motivov, znati bolje (s)promovirati.

Devetnajsto stoletje je bilo stoletje nastanka slovenskega naroda. Zato je logično, da avtor velik del svoje analize nameni temu obdobju. Pri tem jasno poudari, da so kranjsko glasbo v 19. stoletju v veliki meri krojili Čehi, če omenimo le najbolj znane: Franc Sokoll, Gašpar Mašek, Kamilo Mašek, Anton Nedved in Anton Foerster (str. 17-21). Če dodamo še kasneje pomembna Emerika Berana in Hansa Gerstnerja, imamo zaokrožen korpus Čehov, ki so konec 19. stoletja ustvarjali slovensko nacionalno glasbo. Maškova Cäcillia, Foersterjev Cerkveni glasbenik, Nedvědov Nauk o glasbi so prelomna dela, ki so prispevala k slovenski narodni samobitnosti, ki je nato - z Josipom Mantuanijem - dobila tudi svojo strukturno podobo, začela s svojim osamosvajanjem od zgodovine glasbe in si utirala pot na ljubljansko univerzo. Žal neuspešno, a temelji so bili postavljeni. In kot nas uči prilika iz Matejevega evangelija, ni viharja, ki bi odnesel hišo, če ima ta temelje na skali - Mantuani je to skalo postavil, vse ostalo, kar je sledilo, je bilo sicer resda naporno, a vedelo se je, da bo prej kot slej obrodilo rezultate. 
Mantuani pa ni zaslužen samo za postavitev temeljev muzikološke stólice na Univerzi v Ljubljani, ampak tudi za izdajo Gallusovega Opus musicum, ki ga je izdal znotraj zbirke svojega prijatelja in vrhunskega muzikologa Guida Adlerja. A Adler ni vplival samo na Mantuanija, temveč tudi na drugega pomembnega glasbenika in muzikologa Josipa Čerina, ki je pri Adlerju s svojo disertacijo o protestantskih pesmih leta 1902 tudi doktoriral. Barbo (str. 37) ob tem poda droben, a izjemno pomemben podatek, tj. da je bil Čerin prvi doktorand iz muzikologije na Slovenskem. Ta podatek ni samo pomemben, ampak je izjemen za analizo razvoja slovenske muzikologije, ki je - tako si dovolimo reči - zrasla iz dveh stebrov (Mantuanija in Čerina), in ju je povezoval skupni imenovalec - Adler. To ne pomeni le, da smo proforma dobili znanstvenike, ki so se ukvarjali s področjem muzikologije, ampak predvsem to, da je bila že na začetku 20. stoletja slovenska muzikologija vzpostavljena, zrela, da se je lahko kosala s svetovnimi strokovnjaki.

Še eno ime v Barbovi analizi je bilo do sedaj prezrto in neraziskano, čeprav je, kot ugotavlja avtor, »ena nespornih avtoritet na glasbenem področju med vojno« (str. 53) - Anton Dolinar. Razlog za to gre iskati v tem, da je po vojni postal politični emigrant in je bil kot tak izbrisan iz nacionalnega spomina. Krivice, ki se mu je zgodila, ni popravila niti novonastala država leta 1991, prav tako ne stroka. Danes, 29 let po osamosvojitvi, bi ostal dokaj neznan, če mu Barbo ne bi posvetil obsežnega poglavja v svoji knjigi. Naj poudarim, da je dela še veliko, a je to, da je nekdo ime, nad katerim je bil izrečen damnatio memoriae, spet povlekel na plano, veliko delo in velik premik za slovensko muzikološko znanost. ${ }^{1}$

Zadnji del monografije je posvečen umestitvi muzikologije na univerzo. Tu avtor kaže postopen, pronicajoč pritisk Dragotina Cvetka, ki je leta 1961 uspel narediti ta veliki korak in umestiti eno od sedmih ved v sistem Filozofske fakultete Univerze v Ljubljani. Analiza temelji na do sedaj objavljenih člankih, ki jih avtor monografije sam dopolnjuje in kritično ovrednoti, hkrati pa podaja nove podatke, ki so izjemnega pomena in kažejo na to, kako pomembna je muzikologija kot znanost za razvoj Slovenije in njenega narodnega sistema. Na koncu tega opusa Barbo na kratko prikaže tudi življenjepise in dela nekaterih prvih institucionalnih muzikologov, ki jih sam poimenuje "Cvetkovi učenci in nasledniki.« Škoda je, da v ta razdelek ni uvrstil tudi muzikologov mlajše generacije, ki - četudi morda niso bili Cvetkovi učenci - so njegovi nasledniki in nosilci njegove ideje o muzikologiji kot vedi in znanosti.

Knjiga Slovenska muzikologija: kratek prelet po zgodovini Matjaža Barba je več kot le zanimivo branje. Je samoizpraševanje o tem, koliko poznamo svojo zgodovino, ki nas je kot narod ustvarila; kako smo ji zvesti ter predvsem kako se lahko iz svoje preteklosti učimo za boljši jutri. Je pa knjiga tudi opomin, da slovenska muzikologija ni nek raziskovalni nebodijetreba, temveč ključen del študija na univerzi. Brez njene celovitosti in holističnosti si pač študija humanistike, volens nolens, ne moremo predstavljati.

Boštjan Udovič (bostjan.udovic@fdv.uni-lj.si) Fakulteta za družbene vede, Univerza v Ljubljani

1 Z vidika muzikologije bi bilo smiselno natančneje preučiti dejstvo, da je knezoškof Jeglič na Dunaj poslal študirat Antona Dolinarja in ne skladatelja in duhovnika Jožeta Klemenčiča, kar je pri slednjem povzročilo veliko zamero do knezoškofa. To področje ostaja še nepreučeno, nekaj o tem omenja Barbo (str. 55) in Polona Gantar v svojem diplomskem delu "Življenje in delo Josipa Klemenčiča» (Akademija za glasbo, 1997). 